\title{
The Development of Disaster Awareness in Primary Schools to Promote Awareness among Kelompok Kerja Guru (Teacher Working Group) 03 of Silo Sub-district in Jember
}

\author{
Zetti Finali, Muh. Zulfatul A'la, Agustiningsih \\ University of Jember \\ zetti.fkip@unej.ac.id,m.zulfatul@unej.ac.id,ningsihagustin83.fkip@unej.ac.id
}

\begin{abstract}
This project aims to raise the awareness in the Kelompok Kerja Guru or KKG (Teacher Working Group) 03 Silo sub-district, Jember by developing Disaster Awareness in Primary Schools. Efforts to boost the awareness are done through implementing a training in the preparation of disaster-based learning tools and actions that must be taken by the teachers if a disaster occurs. The methods used in this service were (1) discussion on preparedness efforts and the level of teacher's awareness for disasters, (2) teachers training on the concept of disaster awareness in primary schools in the KKG 03 using modules, and (3) teachers assistance in transferring knowledge to students.
\end{abstract}

Keywords: Disaster, Disaster Awareness in Primary Schools, Education

\section{INTRODUCTION}

Silo is one of the sub-districts in Jember Regency with a total area of 13,823.98 Ha. The sub-district shares its borders with the sub-district of Pujer, Bondowoso (to the north), Raung Mountain, Banyuwangi (to the east), the sub-district of Ledokombo (to the south), and Sukowono (to the west). Silo has nine (9) kelurahan (urban villages) spread in every part of the sub-district.

Considering the condition of Silo, which is directly adjacent to Raung Mountain, this area is one of 10 villages that bear the title as one of the regions in the Raung mountain prone eruption map. Raung Mountain is a mountain that is still active until today. Raung Mountain had the status of alert and even standby in 2015. Raung Mountain has a type of strombolian eruption. The characteristic of the strombolian eruption is small eruptions but constantly emitting incandescent material. During the previous time, the eruption of Mount Raung could only be predicted through various signs of initial activity, such as the release of light, high seismicity, roar, and the presence of smoke. The light of fire and the gust of smoke was followed by a throw of incandescent material.

The location of Silo District, which is close to the active mountain, should make the people to be aware of the natural hazards they are likely to face in their own communities. The community generally predicts the eruption based on the knowledge inherited from the older people (i.e parents to their children). This knowledge is derived from the results of observations handed down by their ancestors in observing the activities of the roaring mountain. These signs can be seen by the dry of water springs or the descent of animals from the mountain. However, over time, media and technology have been very helpful in disseminating activities from the erupted volcanoes.

Public awareness in eruption-prone areas is very important to be developed (Wardyaningrum, 2014). Besides the adults, childrens should know the signs of 
volcanic eruptions and the evacuation process (Cicero \& Baum, 2008). This is very crucial because risks and impacts will be significantly reduced if the majority of the people have the knowledge of disaster mitigation. Disaster preparedness must be established, reflecting on the recent natural disasters in Lombok.

As it is paramount to build society's awareness over disaster mitigation, direct or indirect (i.e through media) socialization for the adults was still considered lacking (Astriani \& Hardjono, 2017). Preparing disaster awareness among young generation is essential to be done (Zucker, 2017). The awareness is very determining, especially in eruption-prone area, to help the community when the disaster happens. The enhancement of children's ability in disaster mitigation has become a trend in the past decade (Fox \& Timm, 2008).

Kelompok Kerja Guru (KKG) or Teacher Working Group in Cluster 03 Silo subdistrict is a working group consisting of 11 schools within the disaster-prone area of Raung Mountain. The 11 primary schools included in KKG 03 Silo sub-district are; (1) SDN Garahan 01; (2) SDN Garahan 02; (3) SDN Sidomulyo 01; (4) SDN Sidomulyo 02; (5) SDN Sidomulyo 03; (6) SDN Sidomulyo 04; (7) SDN Sidomulyo 05; (8) SDN Sidomulyo 06; (9) SDN Sidomulyo 07; (10) SDN Sidomulyo 08; and (11) SDN Sidomulyo 09. These schools should have more education regarding disaster mitigation and disaster awareness in pre, on-going, and post disaster time.

The chairman of KKG 03 in Silo Subdistrict, Syahrul Munawir Sadzali, stated in an interview that it is very necessary for enhancing knowledge about disaster awareness to teachers among KKG 03. The enhancement is very important considering the unpredictable disasters which are possible to happen in KKG 03 disaster-prone area.

The chairman also stated that higher class students should be provided with activities relating to disaster to increase the awareness. Higher class students are expected to be able in guarding their juniors when a disaster occurs. This ability will greatly help the parents and fellows besides helping the children themselves to understand the evacuation routes. The positive impact of disaster awareness is that the children would not be the majority of the victims because they also become some part of the disaster management.

Based on the above analysis, the development of disaster awareness in primary schools within KKG 03 Silo subdistrict, Jember, is proposed to promote awareness of the teachers and students. This activity includes a training that can be given to the teachers in the Silo area. The results of these activities can be formulated by the teacher, for example in the effort to develop a learning plan or, specifically, to transform it through training or socialization to the students.

\section{METHODS}

To implement Sekolah Dasar Sadar Bencana (SDSB) or Disaster Awareness in Primary School, this service project used several methods, as follow:

1. Preparing quantitative and qualitative questionnaires, contacting the KKG 03 to discuss, creating Focus Group Discussions, providing quantitative questionnaires, analyzing the data, and interpreting the data. The method used is Focus Group Discussion (FGD). KKG 03 Silo sub-district acted as a participant. Evaluations were done through quantitative and qualitative data on disaster preparedness. Teachers training about the concept of Disaster Awareness in Primary School using modules that have been prepared with the steps taken, such as written tests, lectures on module 1 (disaster concept), 
question and answer, training module 2 (planning process evacuation for schools), question and answer, module 3 training (first aid procedures for victims), question and answer, and written tests. The methods used are tests, lectures, disaster simulations, and role playing. KKG 03 Silo sub-district acted as participants and trainees. Evaluations were done by quantitative data, pretest and post-test in the training, as well as modules that will be used by the teacher.

2. The third and fourth method are assisting teachers and evaluating efforts to develop learning tools based on awareness toward disaster. This method is also done by giving things that the teachers should perform when the disaster occurs (i.e disaster safety education procedures and tools for first aid).

The method used in raising awareness is shown in the chart below:

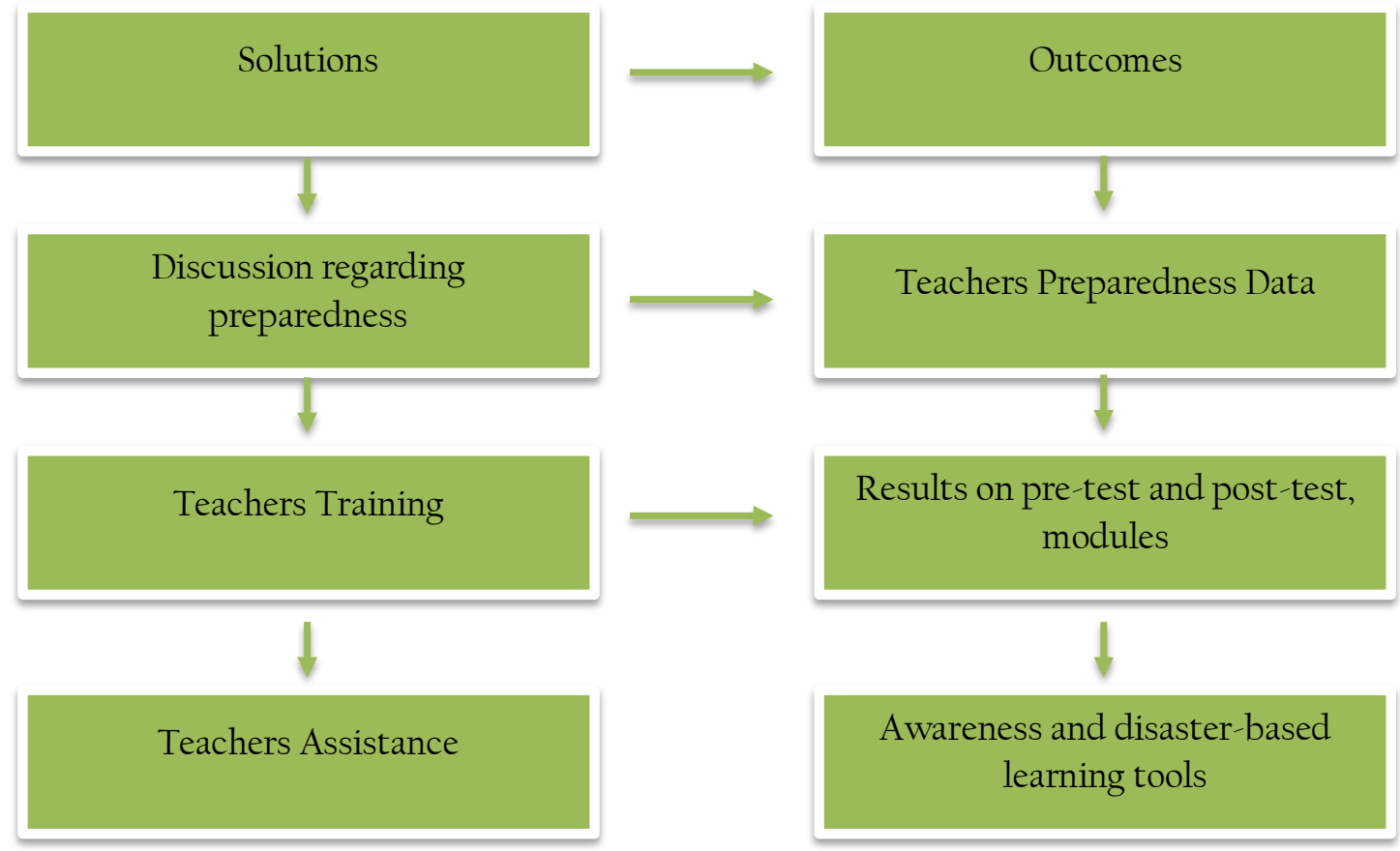

Diagram 1. Diagram of solutions and outcomes toward the problems

\section{RESULTS}

In the first activity, discussion regarding teachers preparedness efforts and awareness toward disaster was expected to result in a deep analysis over the specific issue. This analysis used both quantitative and qualitative approach. The later data became very important as it could be the prime baseline for the team to analyze the needs in doing the planned training. Qualitative approach was also used to strengthen the datas. The qualitative study was done through the method of Focus Group Discussion (FGD). This activity generated basic data regarding the level of teachers preparedness and awareness toward disaster.

After obtaining the basic data on teachers preparedness and awareness for disaster, the team will conduct training according to the data needs that have been analyzed from quantitative and qualitative data. This training was based on the modules that have been prepared by the team (attached). This module contains three (3) modules; a module on the concept of disasters, an evacuation planning process for schools, and a first aid procedure for victims. This transfer of knowledge was expected to expand the knowledge and to foster an attitude of awareness for teachers in the 
KKG 03 Silo sub-district in facing disaster issues. This activity took place in two days. Modules 1 and 2 were conducted on the first day and module 3 was conducted on the second day. The outcomes of the activities were the results from the pretest and posttest regarding knowledge about disaster preparedness. The results depicted the effectiveness of the previous training done by the team to the teachers at Pringgondani Elementary School 02. The other outcomes were modules that have been modified to be implemented in the KKG 03 Silo subdistrict which can be handed for other upcoming teachers trainings.

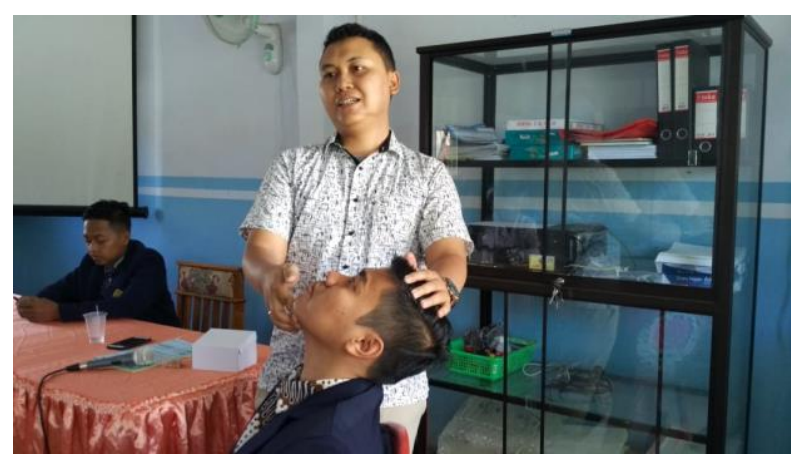

Figure 1. Simulation of first aid procedure for unconsciousness

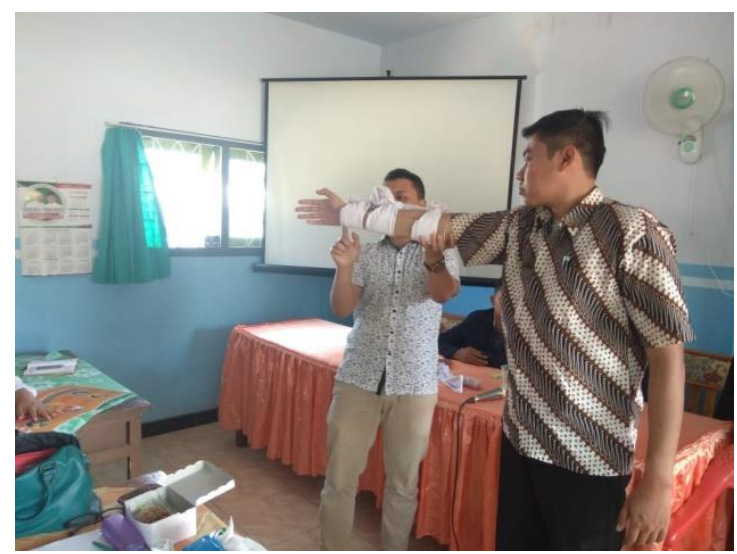

Figure 2. Simulation of first aid procedure for broken bones and fractures

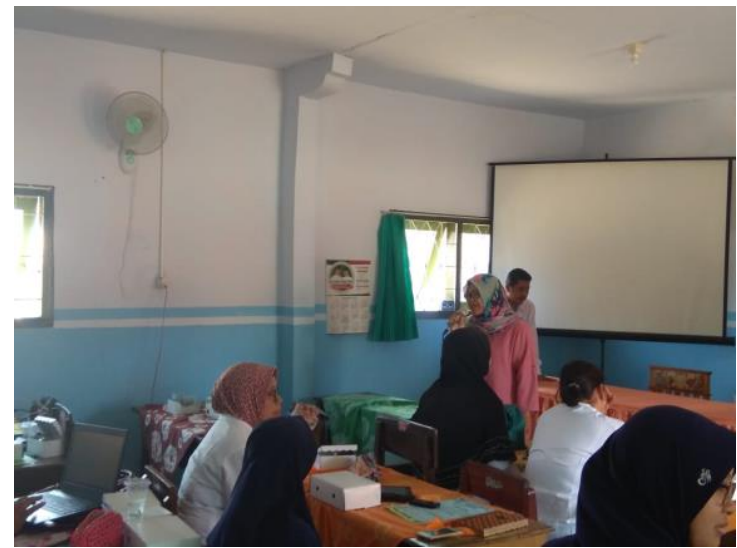

Figure 3. Presentation on awareness value in disaster mitigation

The third and fourth activities were facilitating and evaluating the teachers in the preparation phase of disaster -based learning tools. Assistance and evaluation were 
also done to exemplify actions that must be taken by the teacher regarding emergencies, such as what must be done by the teacher during the disaster.

\section{DISCUSSIONS}

Disaster Awareness in Primary Schools is salient to be developed. Until now, there is still no data that shows that there are elementary schools implementing disaster mitigation value in their curriculum. Clerveaux and Spence (2009) stated that children are a group that is vulnerable when it comes to disaster so there should be an approach to the mitigation process. The transfer of knowledge process also requires an approach to raise the awareness (Wahlstrom \& Louis, 2008). This step encourages children to apply the awareness along with the disaster preparedness. Awareness becomes the basis of education for children, especially in primary education (Suherman, 2009). This is in line with the research of Gelkopf et al (2008) in Sri-Langka which stated that disaster management training (Training of Trainers) for people who influence children, such as teachers, can improve children's ability to withstand disasters.

There has been no pilot form of disaster mitigation learning mechanism with awareness in the literature. Learning-by-playing education method is a form that can be used in elementary school education (Pellegrini et al, 2002). Values regarding disaster can be introduced by playing as long as the teacher's have got the understanding of mitigation. This is the basic foundation of the process of transfer of knowledge about disaster mitigation because teachers are individuals who are always present and close to the students (Pintrich et al, 1993). The team could not indirectly intervene the elementary school students to provide the learning material. Therefore, the team must first give the knowledge to the teachers (Thoonen et al 2011). This is a challenge for this service project. The lesson cannot be directly given to the targeted object but given to the teachers and administrative staffs in the elementary school. Another interesting thing is that the evaluation of the awareness cannot be done once or twice, but done within long-term evaluations.

\section{CONCLUSION}

There are several obstacles which inhibited the KKG 03 Silo subdistric in conducting activities to achieve community-wide awareness about disaster, such as the lack of personnels who have participated in specific training in disaster mitigation, the lack of ability in bringing awareness about disaster in school curricula, the lack of knowledge about first aid procedure for victims of disasters, and the limitations of supporting tools as guidelines in introducing Disaster Awareness in Primary Schools. The efforts to implement Disaster Awareness in Primary School are (1) discussion on preparedness efforts and teacher awareness level toward disasters, (2) teachers training on the concept of disaster awareness, and (3) teachers assistance in transferring knowledge to students. Overall, this activity received a positive response. KKG 03's chairman hoped that there will be a continuation by focusing more on what will be done if the disaster occurs, considering that this service project activity was focused on the prevention of disasters and what should be done after a disaster occurs (emergencies, first aid during a disaster).

\section{BIBLIOGRAPHY}

Astriani, F., \& Hardjono, I. I. (2017). Mitigasi Bencana Gunung Merapi Berbasis Desa Bersaudara (Sister Village) di Kecamatan Musuk Kabupaten Boyolali Jawa Tengah (Doctoral dissertation, Universitas Muhammadiyah Surakarta). 
Cicero, M. X., \& Baum, C. R. (2008). Pediatric disaster preparedness: best planning for the worst-case scenario. Pediatric emergency care, 24(7), 478-481.

Clerveaux, V., \& Spence, B. (2009). The communication of disaster information and knowledge to children using game technique: the disaster awareness game (DAG). International journal of environmental research, 3(2), 209-222

Fox, L., \& Timm, N. (2008). Pediatric issues in disaster preparedness: meeting the educational needs of nurses-are we there yet?. Journal of pediatric nursing, 23(2), 145-152.

Gelkopf, M., Ryan, P., Cotton, S. J., \& Berger, R. (2008). The impact of "training the trainers" course for helping tsunami-survivor children on Sri Lankan disaster volunteer workers. International Journal of Stress Management, 15(2), 117.

Pellegrini, A. D., Kato, K., Blatchford, P., \& Baines, E. (2002). A short-term longitudinal study of children's playground games across the first year of school: implications for social competence and adjustment to school. American Educational Research Journal, 39(4), 991-1015.

Pintrich, P. R., Marx, R. W., \& Boyle, R. A. (1993). Beyond cold conceptual change: The role of motivational beliefs and classroom contextual factors in the process of conceptual change. Review of Educational research, 63(2), 167-199.

Suherman, A. (2009). Pengembangan model pembelajaran outdoor education pendidikan jasmani berbasis kompetensi di Sekolah Dasar. Available in http://jur-nal. upi. edu/file/ayi. pdf.

Thoonen, E. E., Sleegers, P. J., Oort, F. J., Peetsma, T. T., \& Geijsel, F. P. (2011). How to improve teaching practices: The role of teacher motivation, organizational factors, and leadership practices. Educational administration quarterly, 47(3), 496536.

Wahlstrom, K. L., \& Louis, K. S. (2008). How teachers experience principal leadership: The roles of professional community, trust, efficacy, and shared responsibility. Educational administration quarterly, 44(4), 458-495.

Wardyaningrum, D. (2014). Perubahan Komunikasi Masyarakat Dalam Inovasi Mitigasi Bencana di Wilayah Rawan Bencana Gunung Merapi. Jurnal ASPIKOM, 2(3), 179-197. doi: http://dx.doi.org/10.24329/aspikom.v2i3.69

Zucker, I. (2017). Risk mitigation for children exposed to drugs during gestation: A critical role for animal preclinical behavioral testing. Neuroscience e Biobehavioral Reviews, 77, 107-121. 